\title{
Resilience Orchestration and Resilience Facilitation: how government can orchestrate the whole UK ports market with limited resources - the case of UK ports resilience
}

\author{
Duncan R. Shaw ${ }^{1}$, Kamal Achuthan ${ }^{3}$, Ashutosh Sharma ${ }^{1}$, Andrew Grainger ${ }^{2}$ \\ ${ }^{1}$ Nottingham University Business School, Jubilee Campus, Nottingham, UK \\ ${ }^{2}$ Trade Facilitation Consulting, Nottingham, UK \\ ${ }^{3}$ Centre for Transport Studies, Department of Civil, Environmental and Geomatic Engineering, University \\ College London
}

\begin{abstract}
Government departments have limited resources but they are responsible for the healthy functioning of whole markets. This tension is amplified by the opportunities to generate, share and use information from new data sources and digital technologies. Huge increases in volumes and types of data produced by sensors and firms' IT systems can potentially be shared between firms which can cause information overload. This paper uses government orchestration theory to investigate the problems and opportunities of the UK's maritime transport ministry as it supports resilience planning for the whole country's ports system. We build on the developing Lean Government (l- Government) literature by theorizing on the differences between government and other stakeholders. We use a case study to investigate how these differences hinder as well as support the role of a government department. And how the special perspective of an orchestrator can integrate and filter information, motivate diverse collaborators and support the use of orchestration platforms in 1-Government.
\end{abstract}

Keywords: Lean Government, government orchestration, port resilience, integration perspective capability sharing, data sharing

\section{Introduction}

In this paper we study the government's role in resilience planning for the whole UK ports system using the lenses of lean government (1-Government) theory and network orchestration theory. Resilience is the capability of a system to return to or "bounce back" to a normal state after a disturbance or crisis. This capability includes a return to a different stable state that is potentially an improvement on the previous system (Aldunce et al., 2014; Manyena et al., 2011). Resilience planning involves port stakeholders working together to prepare port systems to be more resilient. The UK is an island nation so its sea ports are critical interfaces for most of its international goods trade (Shaw et al., 2017).

We use a case study of a division within the UK's Department for Transport (DfT), to investigate how it influences a country-wide system of organisations and government departments. We focus on the Maritime Resilience Planning team (MRPt) within the DfT's Maritime Security and Resilience Division's (MSRD). And we focus on its orchestration role rather than its policy-making or its regulatory role. The MRPt has limited resources on one hand. And one the other hand it is faced with complex challenges from new digital technologies, from the responsibility for the health of a mixture of public and private markets and from many unforcastable hazards to the resilience of the UK ports system. In order to cope, it has resorted to orchestration practices where it acts indirectly through the work of other stakeholders. We use orchestration theory to make sense of how the MRPt manages this tension and we use l-government theory in turn to understand how a small department can better orchestrate resilience planning for a whole country's ports system (Janssen \& Estevez, 2013; Janssen \& Helbig, 2015). 
Past research has used the capability flow path concept to understand how information could be shared more easily between ports systems stakeholders (Shaw et al., 2017). Information such as what port capabilities are functional or which are available to share. Many factors determine how information is shared between government and other stakeholders (Praditya et al., 2017).We seek to understand how to help the DfT to motivate ports stakeholders; coordinate their capabilities to prepare for unforecastable crises; and better use the vast range of sensors, business IT systems and other information resources that are available within the UK transport industry. This includes data which is increasingly collected by public-private information platforms and international trade platforms (Klievink et al., 2016; Bharosa et al. 2013). Our research question is how and why can ports system stakeholders be helped and motivated to work together more smoothly by sharing information and capabilities in resilience planning? Why they would cooperate and how would they do it? The governance of these activities and the architectural mechanisms which facilitate many stakeholders working together are common themes in the literature and we reflect this in our focus on platforms and studying the approach to orchestration (Praditya et al, 2017; Klievink et al., 2016; Brown et al., 2017).

First we describe the theoretical background of network orchestration in the context of the 1Government and related literatures and then we introduce the resilience planning literature. Next we explain our research process based on long term access to a government department and other industry stakeholders. Then we use a rich and diverse set of examples from our research to show how capability sharing is orchestrated by government. And how it could be improved. We conceptualise the special perspective of government as something which brings benefits as well as challenges when faced with using the new digital resources of a whole market. Finally, we use our theoretical ideas to suggest how to orchestrate the finding of alternative capabilities in the UK ports system; how stakeholders can be motivated to share them; and how this might benefit researchers and managers working in this area.

\section{Theoretical background}

\subsection{Orchestrating networks using platforms in a Lean Government approach}

Orchestrators are organisations which have a system-level role that is qualitatively different from the roles of the other organisations in the system. Different aspects of network orchestration include enacting and developing government policy (Janssen \& Estevez, 2013; Janssen \& Helbig, 2015); setting the vision and focusing members (Moller et al. 2005); mobilizing resources, delegation, dividing up roles, facilitation and integration (Goerzen, 2005; Lorenzoni \& Lipparini, 1999; Shaw, 2007); knowledge transfers among network members and network-level learning (Lorenzoni \& Lipparini, 1999); coordination, configuration and reconfiguration of the network to adapt to change (Hinterhuber 2002; Goerzen, 2005; Shaw, 2007); and value creation (Moller \& Svahn, 2006; Dhanaraj \& Parkhe 2006). Fundamentally, an orchestrator does not own other network members (Dhanaraj \& Parkhe, 2006; van Heck \& Vervest, 2007; Moller et al., 2005; Moller \& Svahn, 2006).

Lean Government (1-Government) concepts refine the wider orchestration literature in the context of mixed of public and private agencies and in terms of how and why orchestration is done. The 1-Government approach orchestrates stakeholders to use their combined capabilities to mutually help each other to do more with less resources using public-private platforms (Janssen \& Estevez, 2013; Klievink at., 2016). 1-Government is an appropriate theoretical lens because UK ports are extremely specialised, they lack internal redundancy 
and crises are unforecastable. So a means of mutually sharing capabilities presents a possible way for a directorate with few resources to help a whole national market. This is important because the UK imports $50 \%$ of its food and $91 \%$ of this comes by sea. For a full description of the role of ports and the resilience and information sharing issues that ports firms and government are faced with please see Shaw et al. (2017).

Orchestrating in this sense means that government directs and influences and is not directly involved in the production activities of ports. This means decoupling "steering" activities like policy-making and regulation from "rowing" activities such as service-delivery and compliance checking (Osborne \& Gaebler, 1993). Decoupling is enabled by using platforms to integrate stakeholders and to share their capabilities and resources, which include information. An orchestrator builds the network that it influences, even if is a subset of an already functioning system. It picks appropriate participants, motivates them to join, influences them and then checks that their behaviour fulfils their role. It also facilitates the building of environments in which this can happen.

These environments are commonly digital platforms which help stakeholders to find other stakeholders who can help them. This is because in orchestrated networks it is other participants which provide nearly all the capabilities, not the orchestrator. The link between a network orchestrator and the network platform is that the orchestrator builds or at least governs the platform in a way which supports its orchestration aims. Platforms are the means of organisation and the means of orchestration. Platforms link stakeholders so that they can share each other's capabilities and resources in various ways, which are mutually beneficial and which create higher level products or services (de Reuverlet al., 2017; Janssen \& van der Voort, 2016; Iyer \& Davenport, 2008; Iansiti \& Levien, 2004). Platforms support new ways of value creation and collaboration. They use some form of information infrastructure to organize a network of stakeholders and they create new business models.

Platforms can be non-digital or digital. They can be one, two or multisided with each 'side' being a category of stakeholder. Platforms facilitate the sharing of information and other capabilities based on that information (Klievink at., 2016; Brown et al., 2017, Bharosa et al. 2013). Brown et al. group the research on inter-organisational platforms into three dimensions (2017). The first is how a platform's organisational form is collectively visualised to support use and innovation. The second is a dynamic view of how market forces drive change within the makeup of stakeholders, their product and service innovations and how they use the platform. The third is a 'snap shot' view of how the architectural structure of the platform enables firms to link business processes together in a modular manner. These three dimensions constitute a typology of platform strategies which can be used to collectively characterise a platform. l-Government is concerned with many-sided platforms which governments use as "regulated environments" to manage the other stakeholders (Janssen \& Estevez, 2013).

Recent orchestration research has focused on mixed public and private sector networks. The platform and orchestration aspects of 1-Government are fast developing areas of research. But more research is needed into how orchestration platforms are designed, governed and operated. And how public and private organisations can be motivated to use platforms and to participate in orchestrated activities in order to create mutual benefits (Janssen \& Helbig, 2015, Janssen \& Estevez, 2013). In this study we investigate how an orchestrator can aggregate, quality check and use the vast amounts of data which can now be collected through new forms of digital connections and communications (Janssen \& Helbig, 2015). 
Shaw DR, Achuthan K, Sharma A and Grainger A (2019) Resilience Orchestration and Resilience Facilitation: how government can orchestrate the whole UK ports market with limited resources - the case of UK ports resilience, Government Information Quarterly, (in press).

\subsection{The complex nature of ports resilience planning}

Resilience planning is a major part of government because the first priority of a government is to ensure the functioning of society. Port resilience is a subset of the disaster resilience literature which deals with the operation of ports (Achuthan et al., 2015). In the UK port resilience work runs in parallel to work on safeguarding all other Critical National Infrastructure. Port resilience researchers have studied the roles of different port stakeholders (Becker and Caldwell, 2015; Shaw et al., 2017); stakeholder interdependency and coopetition (Hsieh et al., 2014); finding alternative ports to use (Akakura et al., 2015); port bottlenecks (Trepte \& Rice, 2014); and port network capacity simulations (Paul \& Maloni, 2010). But there has been little research into how the many ports stakeholders can be orchestrated by a single organisation to improve resilience planning. Maritime ports are complex operational systems with many different types of stakeholders, for example shipping lines, terminal operators, harbour masters, storage firms, cargo processors, passengers, local residents, transport firms and logistics service providers (Becker \& Caldwell, 2015). Their interests are seldom aligned and there is an urgent need for the UK ports sector to improve its resilience planning (Davies, 2014, Achuthan et al., 2015).

Information sharing opportunities and barriers are a major aspect of the complexity of ports. Port stakeholders depend on each other's capabilities to provide services, people, cargo and information. The flow of goods to, through and beyond a port has been conceptualised by the capability flow path. This is the serially linked set of capabilities which enable the purpose of a port (Shaw et al., 2017). A port system's highly interlinked capabilities mean that when a crisis removes one capability it will have a cascading effect on other capabilities (Hsieh et al., 2014). The close interlinking also means that port stakeholders might sometimes help each other by sharing spares, work-arounds and other alternative capabilities (Akakura et al., 2015). However, this requires that the complexity generated by such interdependence must be managed by sharing information in some way (Comfort et al., 2001; Welsh, 2014).

Sharing information helps to promote sharing capabilities but there are complex barriers to sharing assets and customers. Many specialised equipment cannot be moved e.g. container cranes. Some equipment requires trained operators or perhaps the equipment cannot be moved in time. Sometimes are the barriers are commercial. For example, if customers are forced to seek new ports then they will not return once shared equipment are returned. One a whole port level, some owners of multiple ports would first try to replace the loss of a UK port by using their European ports. Even sharing data raises the concern that Government and competitors might use the information to oppose planning applications for site development.

We have summarised the interrelations between the concepts of network orchestration, 1government and platforms together with the complexity problems generated by ports resilience planning in Figure 1. 
Shaw DR, Achuthan K, Sharma A and Grainger A (2019) Resilience Orchestration and Resilience Facilitation: how government can orchestrate the whole UK ports market with limited resources - the case of UK ports resilience, Government Information Quarterly, (in press).

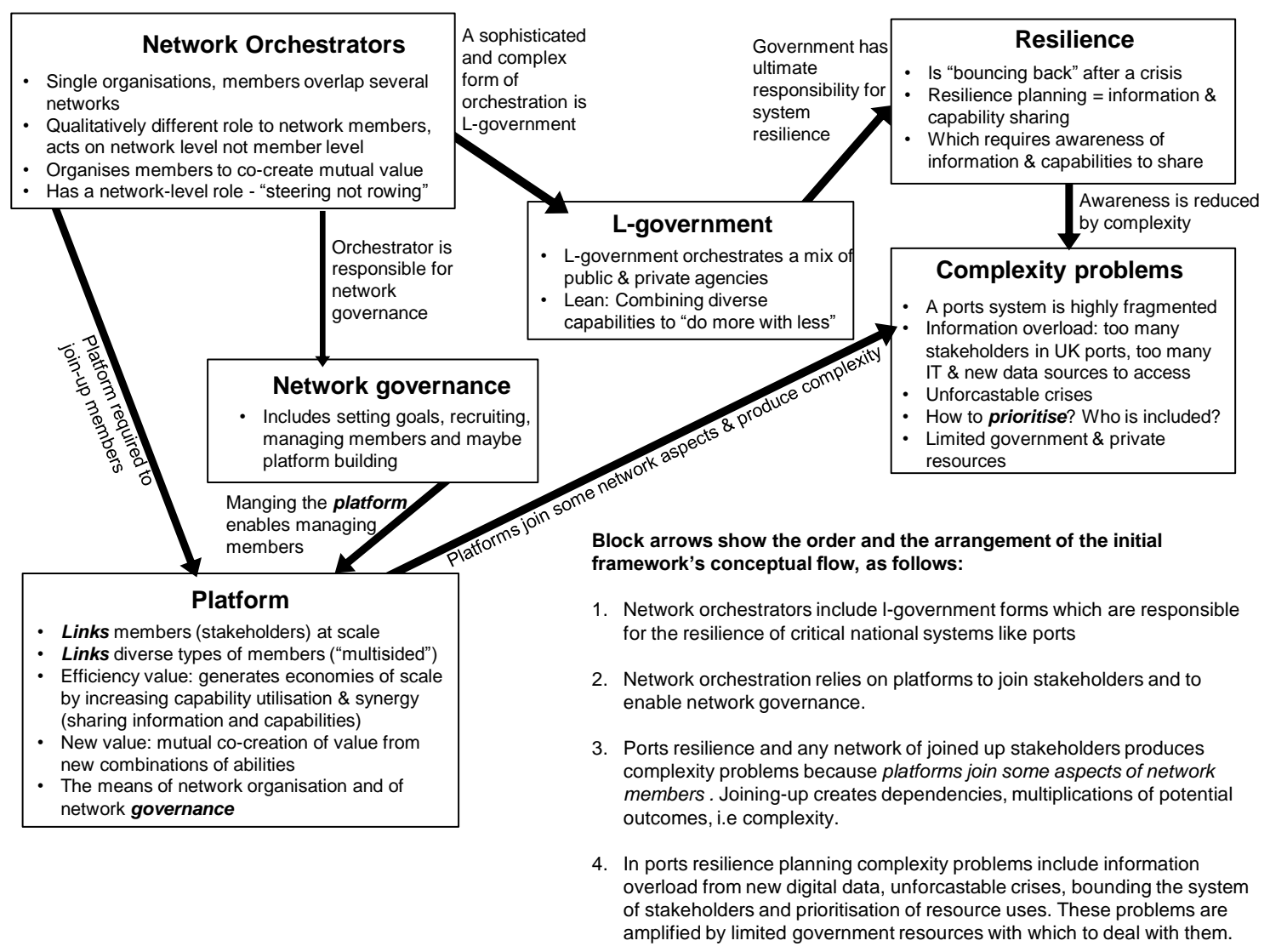

Figure 1: Initial conceptual framework.

\section{Method}

\subsection{Sample and context}

Our objective was to understand how government can support better resilience planning. We used a qualitative approach as we were interested in subjective questions of "how" and "why" rather than of "how many". We focused on the subjective needs of different stakeholders for information about alternative capabilities which could substitute for capabilities damaged in a crisis. These are the main ingredients of a resilience plan. We followed Yin's case study approach to answer questions of "how" and "why" (2003). Case studies are useful for investigating contemporary phenomena, which researchers have no control over (Eisenhardt, 1989). They are also a valid approach for information systems research (Benbasat et al, 1987; Lee, 1989). A case study approach fitted well with our investigation of the information flows between the government and ports firms. We were concerned with complex dynamic phenomena so we used several different data collection methods and many different data sources (ibid). In our investigation we followed Yin's advice on embedded case studies because our research question was about a single system of national ports (2003). But we were interested in the interrelations of phenomena on different levels of analysis rather than just the global nature of the system. We chose case sub-units which gave us opportunities for analysing the resilience planning interactions between stakeholders, whilst anchoring us in the context of the overall case.

\subsection{Data}


We collected data from January 2010 to May 2018. During this period we held semistructured interviews, workshops and meetings with the managers and staff of the Department for Transport (DfT), port landlords and other port system organisations. We selected the interview participants and their firms so that they covered a range of UK ports as well as a range of different types of port stakeholders. This included ship operators, harbour masters port, landlords, logistics firms and government departments. The interviews lasted between 30 minutes and 2 hours. See Table I for examples. We validated our emerging findings at meetings with participants to listen to their feedback, and we frequently published validation documents to test our ideas and gain comments. Also, one of the authors was seconded from his university to the DfT for 2 years during this period to advise on simulating crises in ports and another author was sponsored by the DfT in a PhD research project from 2015 to 2019. This extended research access provided multiple opportunities for unstructured exploration of different aspects of the case. We used it to test our emerging conceptualisations of the case phenomena on multiple occasions and with a range of different participants. Our frequent, varied and longitudinal contact gave us valuable feedback on how well our ideas fitted with participants' interpretations of how relevant our ideas were. And it also helped to increase trust and the levels of disclosure.

\begin{tabular}{|c|c|c|}
\hline $\begin{array}{c}\text { Stakeholder } \\
\text { type }\end{array}$ & Stakeholder(s) & $\begin{array}{l}\text { Type of } \\
\text { meeting }\end{array}$ \\
\hline \multirow{6}{*}{$\begin{array}{l}\text { Government } \\
\text { department } \\
\text { (NB: The DfT, } \\
\text { the MSRD and } \\
\text { the MRPt are not } \\
\text { always the lead } \\
\text { actor in } \\
\text { activities) }\end{array}$} & Cabinet Office & Interviews \\
\hline & Defra - two workshops and an interview & Workshop \\
\hline & $\begin{array}{l}\text { DfT - multiple interviews, meetings and } \\
\text { informal communications }\end{array}$ & Interview \\
\hline & $\begin{array}{l}\text { DfT- Big Data workshop with Resilience } \\
\text { Head and data analysts }\end{array}$ & Workshop \\
\hline & Meeting with DfT and DECC & Workshop \\
\hline & UK Transport Minister, Stephen Hammond & Presentation \\
\hline Customs & World Customers Union meeting & Presentation \\
\hline $\begin{array}{l}\text { Satellite data } \\
\text { sources }\end{array}$ & Satellite data providers & Workshop \\
\hline Ferry operator & DFDS - Immingham & Interview \\
\hline \multirow{4}{*}{$\begin{array}{l}\text { Industry } \\
\text { Association }\end{array}$} & British Harbour Masters Association & Conference \\
\hline & Int. Assoc.of Maritime Economists & Presentation \\
\hline & UK Major Ports Group - three meetings & Interview \\
\hline & $\begin{array}{l}\text { UK Major Port Group, British Ports } \\
\text { Association and UK Chamber of Shipping }\end{array}$ & Workshop \\
\hline \multirow{5}{*}{$\begin{array}{l}\text { Mixed } \\
\text { stakeholder } \\
\text { group }\end{array}$} & DfT hosted workshop with UK port sector & Workshop \\
\hline & Montgomery Exercise & Workshop \\
\hline & South East Ports Group (twice) & Workshop \\
\hline & Tidal surge workshop & Workshop \\
\hline & UK Ports and DfT & Workshop \\
\hline
\end{tabular}


Shaw DR, Achuthan K, Sharma A and Grainger A (2019) Resilience Orchestration and Resilience Facilitation: how government can orchestrate the whole UK ports market with limited resources - the case of UK ports resilience, Government Information Quarterly, (in press).

\begin{tabular}{|c|c|c|c|c|}
\hline & \multicolumn{3}{|c|}{$\begin{array}{l}\text { Multi-stakeholder validation workshop } \\
\text { hosted by the DfT }\end{array}$} & Presentation \\
\hline \multirow{3}{*}{ Port operator } & \multicolumn{2}{|c|}{$\begin{array}{l}\text { Ports: Southampton, Dover, } \\
\text { Grimsby, Harwich, Tilbury }\end{array}$} & \multicolumn{2}{|c|}{$\begin{array}{l}\text { Interviews, workshops, } \\
\text { meetings }\end{array}$} \\
\hline & Immingham port & \multicolumn{3}{|c|}{\begin{tabular}{|l|} 
Interviews, observations and user \\
groups meetings (April/ May 2018)
\end{tabular}} \\
\hline & $\begin{array}{l}\text { Port of London } \\
\text { Authority }\end{array}$ & \multicolumn{3}{|c|}{$\begin{array}{l}\text { Meetings, workshops and interviews (3 } \\
\text { February } 2011 \text { and } 4 \text { September 2013) }\end{array}$} \\
\hline Port stakeholders & \multicolumn{3}{|c|}{$\begin{array}{l}\text { Oil supplier, estuary services, moorings } \\
\text { firm, towing firm, container services, police }\end{array}$} & Interviews \\
\hline Power station & \multicolumn{3}{|l|}{ Drax (twice) } & Interview \\
\hline
\end{tabular}

Table I: Summary of main meetings with stakeholders and their organisational types.

We collected data from meeting notes and telephone conversations, meeting reports and informal conversations that were supplemented by the participants' internal reports and their website content. We interviewed participants in their offices or the offices of other participants, for example we interviewed many staff and partners of a major ports operating group as part of their internal business continuity programme. All interviews and meetings were recorded using detailed paper notes because of the commercial and politically sensitive nature of some of the subjects of discussion. All notes were then discussed between at least two of the four authors to minimise researcher bias and to triangulate for emerging ideas.

\subsection{Data Analysis}

We chose a social science approach because port resilience planning intersects the different social systems that are focused on UK ports including public policy and administration, business, transport and law. We used a qualitative approach because the influencing mechanisms which might be used to motivate participants to share resources, capabilities or information were subjective. Also, we studied complex organisational processes as we wanted to show "what precedes what", which was another reason to use a qualitative approach (Miles \& Huberman, 1994). We used an interpretive approach that was based on hermeneutics. Hermeneutics is a major branch of interpretive philosophy and we used Klein and Myers' hermeneutic principles for conducting and evaluating interpretive field research (1999). Hermeneutics is based on the idea that an understanding of a whole system comes from contrasting preconceptions and new understandings gained from studying a system's parts and their different interrelationships. In hermeneutics the process of interpretation is cyclical. Researchers move from an initial understanding of the parts, to an understanding of the whole. Then from an understanding of the whole to contrasting it with the surrounding context of the whole and finally, back to a more developed understanding of the parts (ibid). This approach is particularly useful for analysing complex cases because the bounding of researchers' information gathering and processing capabilities is mitigated by a repeating cycle of studying different relationships in a much wider system. Which is too complex to be considered at once. It also suited our long term research relationships.

In our investigation we cycled between multiple levels including the level of all UK ports, the level of rivers with several ports, the whole port level of the port operator and the operational levels of individual port firms. This enabled us to perceive an interdependent whole (Klein \& 
Myers, 1999; Chalmers, 2004). We chose the case of the UK ports system as an extreme case because its multiple levels of government, of river or region holding several ports and of port landlord and port operations firms (Eisenhardt, 1989). The case was special because of our access to multiple levels and 'rhythms' of government, from the Minister to day-to-day operations (Janssen \& van der Voort, 2016). This allowed us to perceive the multi-level contexts of how information flowed between stakeholders, which cases with other system boundaries would not provide (Siggelkow, 2007).

Klein and Myers' hermeneutic principles (1999) are as follows: 1. The Hermeneutic Circleinterpret sensory data by cycling between the parts and the whole of a system. Data, organisations and material objects, plus researchers and participants are counted as parts. 2 . Contextualization - consider the social and historical "back story" of the case. How and why was the case data produced by the case phenomena? 3. Interaction between Researchers and Subjects - how is the case data socially constructed by participants interacting with them? Consider and question research assumptions. 4. Abstraction and Generalization - identify links between the idiographic level of the case and the wider literature. Test theoretical contributions and link to external literatures. 5. Dialogical Reasoning - explain researchers' initial biases and preconceptions. Describe how and why the initial conceptual lens of the investigation changed. How did different concepts promote an understanding, or misunderstanding, of the case situation? 6. Multiple Interpretations - did researchers and participants have different perspectives on the same situation and make different interpretations? 7. Suspicion - look for socially created distortions of participants' accounts of the case situation. Not as truths or falsehoods but due to commercial or political sensitivities systematically influencing actors' the words. Finally, researchers must consider how these principles interrelate within their research process. This is a processual, multiperspective and iterative approach that is particularly appropriate for a study of how to orchestrate multiple participants working together in new ways.

\section{Case analysis}

In the UK the Department for Transport (DfT) is tasked with supporting the country's transport network. The roads, railways, aviation and maritime transport infrastructure such as ports (DfT, 2018a). Our focus was on the Maritime Resilience Planning Team (MRPt), which was part of the Maritime Security and Resilience Division (MSRD). Which was part of the Maritime Directorate. In turn this was part of the International, Security and Environment Group, one of six groups that made up the DfT (DfT, 2015a, DfT, 2018b). The MSRD's general objectives was to maintain and develop the security and resilience of maritime transport for UK ports and UK flagged ships around the world (DfT, 2015b). The DfT is a large government ministry and during our research there were between four and five staff in the MRPt. In this study we focused on how the MRPt helped port stakeholders to work together to make port systems more resilient.

Each port has many stakeholders and the UK ports system has many levels of organisation. On the port level, stakeholders include shipping firms, harbour masters, terminal operators, warehouse operators, logistics service providers, haulage firms and many other port users. 
SYSTEM LEVELS

\section{Platforms have to "bridge" inter-system gaps by transmission and/ or translation. Any gaps need new platforms. Platforms are a mixture of information system bridges and organisational bridges.}

\section{A PORT SYSTEM LEVELS}

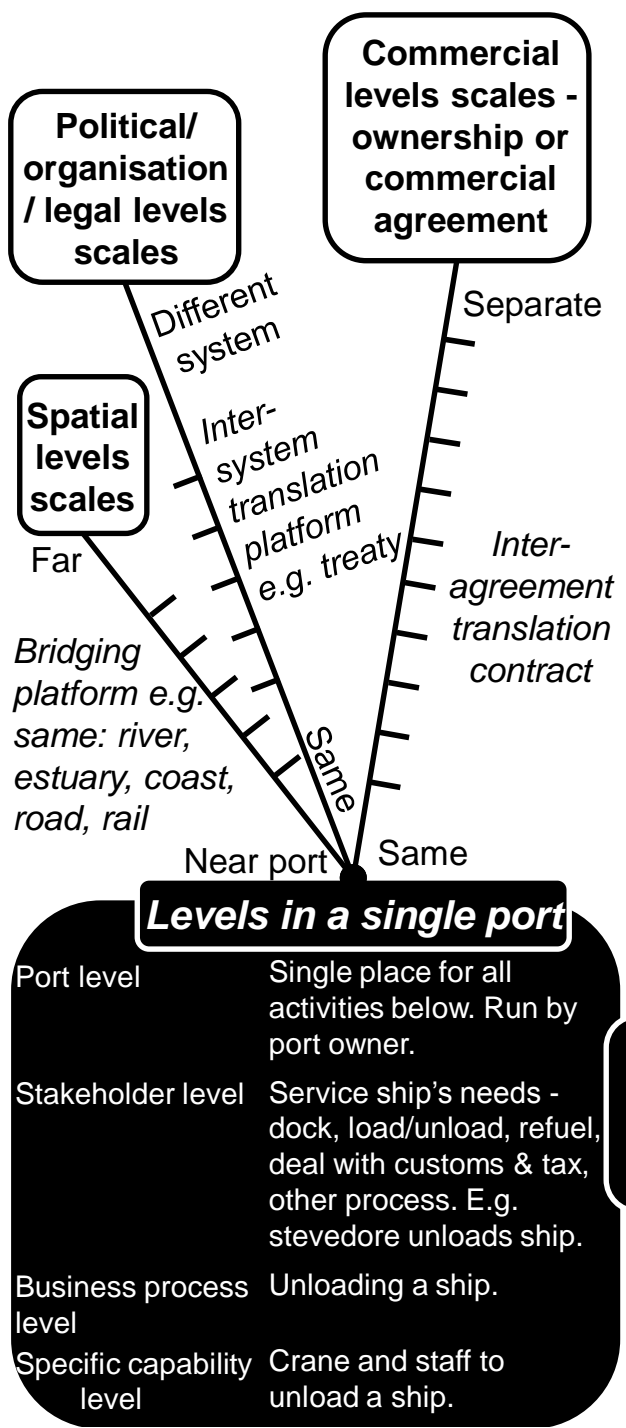

B EXISTING government and private organisational structures above the level of one port

(Dashed lines show reducing organisational levels)
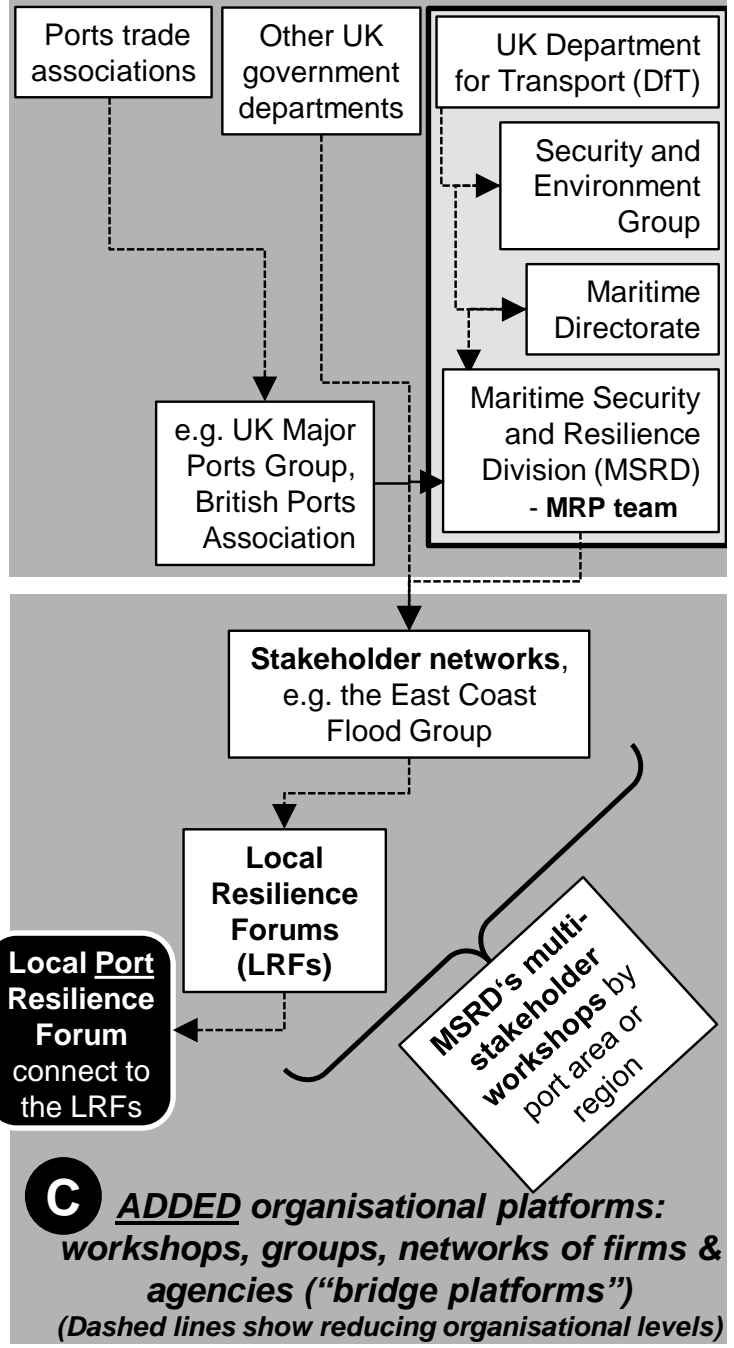

Figure 2: The multiple levels of the ports system of government and other organisations, and the platforms that span them. (A) The ports system has levels above a single port which depend on one's perspective, which include but not be limited to spatial, political/organisational/ legal and commercial levels. "Levels" here means intersystem gaps which need bridging. (B) EXISTING Government and private organisational structures bridge some gaps. (C) Government bridges other gaps with $A D D E D$ organisations. E.g. by setting up networks and forums, running workshops. Each stakeholder organisation has their own IT systems, information and capabilities. 
The MRPt encouraged each port to produce a resilience plan for the whole port to explain what would be done if certain crises occurred (Shaw et al., 2017). On a higher level, the MRPt connected ports stakeholders with stakeholders from outside the port boundary. For example, Local Resilience Forums (LRFs) covered the same areas as regional police forces. They were usually led by local authorities and consisted of representatives from blue light responders and other stakeholders as needed. They also included organisations that were based outside of ports such as local public services, emergency services, local authorities, the NHS, the Environment Agency, the Highways Agency, utility companies and others (GOV, 2018). On a yet higher level of the UK ports system there were other stakeholder networks. For example, the Department for Environment, Food and Rural Affairs (Defra) led the East Coast Flood Group which included coastal Local Resilience Forums (LRFs), the Environment Agency, the Meteorological (Met) Office, utility firms, the Emergency Planning Society, voluntary sector organisations, the UK's Central Government Group for coastal flooding and other UK government departments (Powell, 2015). The East Coast Flood Group acted as a two-way connection between policy-making processes of the DfT, other government departments and the UK's East Coast ports. It focused on tidal surges and other coastal flooding risks. Port Resilience Forums were created as sub-forums by the MRPt to connect to the LRFs. The MRPt also organised multi-stakeholder workshops in each port or port region to either highlight important risks or to bridge gaps between stakeholders where there were none before. There were also trade associations like the UK Major Ports Group and the British Ports Association.

We have summarised the multiple levels of the UK ports system and the platforms that span them in Figure 2. In Figure 2 the "level" boundaries are obvious gaps between the subsystems of the whole ports system. "Intersystem gaps" are where subsystems of the whole ports system are not already linked by some medium of connection, e.g. ownership or common control. We viewed these gaps in terms of spatial, political/ organisational/ legal and commercial issues because these are important contexts for the resilience of this system. Other lenses could be used to view the same system and they would suggest other level architectures. Here we have only included those which are concerned with resilience planning. The gaps make the structure of the ports sub-system boundaries easy to perceive. But these same gaps must be bridged by different platforms in order to plan for ports resilience across the whole system.

\subsection{The complexities of defining the role of the MRPt.}

The general objectives of the MSRD relating to security were clear but its precise role in resilience planning was very difficult to communicate to our researchers. The general objectives were to safeguard the UK's maritime transport systems. These included an "all encompassing" list of areas such as inspections, counter piracy, international engagement, stakeholder engagement, medical hazards, advice and guidance and resilience (DfT, 2016) But how it should do this was not defined in any document focused in resilience planning that we could find. In interviews with MRPt we found that this vagueness was due to a number of factors including the unforcastability of crises, a lack of regulatory power over port stakeholders and the complexity of the network of stakeholders that operated and used UK ports. The mission of the overall DfT was clear (DfT, 2018a). At the level of the MRPt we found that the operational definition of the role was broad. For example, the welcome booklet that new staff received said that the MRPt's role was to protect ports against risks which included extreme weather (DfT, 2016). In the Maritime Director Information Pack the 
MSRD's Interim Deputy Director said that the MSRD's aim was to protect maritime transport. Which covered UK ports and UK and Red Ensign flagged ships wherever they were all round the world (Rowan, 2015). And during our research with the MRPt their emphasis was on physical port infrastructure and port operations. This included what they called a cycle of "Readiness, Response, Recovery and Resumption" (GFG, 2016).

A more precise definition of the scope of the MRPt's role was important because every action they made was in the public view and afterwards it was closely scrutinised by the media and by politicians. The MRPt was a small number of people with limited resources. So defining the scope of its role was also critical for prioritising the use of those resources. But defining exactly where they should intervene was very difficult because every risk was different, and then every actual incident was different, and all parts of the transport system were linked to each other. So it was difficult to say where the role of the MRPt stopped. They frequently asked themselves "Where does the list of stakeholders that we need to support end?" For example, should they have included dry-side as well as wet-side port operators when organising meetings or email lists? Should they have included shipping firms as well as portbased firms? Should the scope of their responsibility have stopped at the port's loading and unloading terminals or should it have included the roads that haulage firms used to get to and from a port?

The resilience part of MSRD's role has always been rooted in the UK's Civil Contingencies Act 2004 which describes the responsibilities of Harbour Authorities in crisis planning (MCA, 2016). More recently security risks had come to the fore, which were handled by the security teams within MSRD. The dynamic nature of both resilience risks and changes in the political environment such as Brexit, meant that the MRPt's role was fluid.

\subsection{The complexities of working with ports system stakeholders to increase resilience}

The UK ports system consisted of all the ports around the coastline of the UK and those accessible by major waterways, the many firms and individuals that worked in and used each port and the UK government departments with responsibilities that would be affected by a loss in the capabilities that the ports provided. From interviews with the MRPt we identified 17 areas of stakeholders. Each stakeholder area had different roles and concerns and each UK port had a different mix of stakeholder types according to the port's cargo specialisation (see Table 2). However, the stakeholders that the staff had to deal with included many more than this depending on which aspects of the UK maritime transport system they were concerned with at the time.

\begin{tabular}{|l|l|l|}
\hline $\begin{array}{c}\text { Stakeholder area of } \\
\text { work }\end{array}$ & \multicolumn{1}{|c|}{ Role } & \multicolumn{1}{|c|}{ Examples of concerns } \\
\hline Port/terminal operator & $\begin{array}{l}\text { Loading/unloading, storage, } \\
\text { throughput, stevedores, crane } \\
\text { operators, mooring/berthing, } \\
\text { piloting, sorting, packaging, } \\
\text { dredging, contracts and fees }\end{array}$ & $\begin{array}{l}\text { Capacity and labour planning, } \\
\text { forecasting ship movements } \\
\text { and cargo types, cargo state of } \\
\text { readiness for unloading (e.g. } \\
\text { frozen). }\end{array}$ \\
\hline Tenants & $\begin{array}{l}\text { Processing, manufacture, repairs, } \\
\text { provisions, bunkering and storage. }\end{array}$ & $\begin{array}{l}\text { Facilitating raw material } \\
\text { arrival, vehicle repacking and } \\
\text { finished product output }\end{array}$ \\
\hline Workforce & $\begin{array}{l}\text { Sorting, loading/ unloading, } \\
\text { storage, modal transfer }\end{array}$ & $\begin{array}{l}\text { Detailed instructions of where, } \\
\text { when and what to do }\end{array}$ \\
\hline
\end{tabular}




\begin{tabular}{|c|c|c|}
\hline Ship operators & $\begin{array}{l}\text { Cargo pick-up, transport by water } \\
\text { and delivery }\end{array}$ & $\begin{array}{l}\text { Where to dock and how long } \\
\text { for, refuelling, customs }\end{array}$ \\
\hline Inland freight hauliers & $\begin{array}{l}\text { Cargo pick-up and drop off, } \\
\text { within-port transfers }\end{array}$ & $\begin{array}{l}\text { Locations, driver hospitality, } \\
\text { timing, cargo details, parking }\end{array}$ \\
\hline Coastguard & Safety and rescue & Responsibility scope and risks \\
\hline $\begin{array}{l}\text { Utilities and Statutory } \\
\text { undertakers }\end{array}$ & $\begin{array}{l}\text { Provision of power, } \\
\text { communications, water }\end{array}$ & $\begin{array}{l}\text { Demand and user needs, port } \\
\text { expansion, new electric ships }\end{array}$ \\
\hline Emergency responders & First at the scene of event & Responsibility scope and risks \\
\hline Inland transport & $\begin{array}{l}\text { Network Rail (rail infrastructure), } \\
\text { freight operating companies, } \\
\text { Highways England (highway } \\
\text { infrastructure), Local Highways } \\
\text { Authorities, freight trains }\end{array}$ & $\begin{array}{l}\text { Responsibility scope and } \\
\text { service levels, safety } \\
\text { (especially passengers), port } \\
\text { expansion plans and use } \\
\text { pattern changes }\end{array}$ \\
\hline Nearby stakeholders & $\begin{array}{l}\text { Marinas, leisure craft, local } \\
\text { transport, communities, natural } \\
\text { habitats, sea life and birds }\end{array}$ & $\begin{array}{l}\text { Boundaries, permissions, } \\
\text { contact numbers, } \\
\text { environmental testing }\end{array}$ \\
\hline Port authorities & $\begin{array}{l}\text { Safety, environmental issues, port } \\
\text { security, port police, navigation, } \\
\text { local vessel traffic management }\end{array}$ & $\begin{array}{l}\text { Port stakeholders' business } \\
\text { details, environmental testing, } \\
\text { integration of stakeholders }\end{array}$ \\
\hline $\begin{array}{l}\text { Freight brokers, carriers, } \\
\text { shippers }\end{array}$ & $\begin{array}{l}\text { Supply chain operations, } \\
\text { inventory control, cargo } \\
\text { manifesting, insurance, financing, } \\
\text { legal services }\end{array}$ & $\begin{array}{l}\text { Supply chain management } \\
\text { data, financial and other } \\
\text { business information }\end{array}$ \\
\hline $\begin{array}{l}\text { Specialist marine } \\
\text { engineers }\end{array}$ & Site-specific analysis and works & $\begin{array}{l}\text { Asset purpose and history } \\
\text { information }\end{array}$ \\
\hline $\begin{array}{l}\text { Local and Central } \\
\text { Government }\end{array}$ & $\begin{array}{l}\text { National resilience planning, } \\
\text { monitor safety and security } \\
\text { regulations, free up finance in } \\
\text { times of stress, apply hazmat } \\
\text { incident rules and regulations. } \\
\text { Includes: Defra, the Environment } \\
\text { Agency, the Marine Accident } \\
\text { Investigation Branch, HM } \\
\text { Revenue and Customs, UK Border } \\
\text { Agency, Port Health Authority } \\
\text { Inspectors, the Health and Safety } \\
\text { Executive, Local Enterprise } \\
\text { Partnerships }\end{array}$ & $\begin{array}{l}\text { Port resilience preparation } \\
\text { information: contact details, } \\
\text { information sources, scope of } \\
\text { authority information, } \\
\text { pathways for decision } \\
\text { escalation, awareness and } \\
\text { broadcasting mechanisms, } \\
\text { scenario planning, simulation } \\
\text { models and joint exercises, } \\
\text { port development plans }\end{array}$ \\
\hline Unions & Supporting members & Working conditions and hours \\
\hline $\begin{array}{l}\text { Local Resilience } \\
\text { Forums (LRFs) }\end{array}$ & $\begin{array}{l}\text { Pre-planning and development of } \\
\text { incident management protocols } \\
\text { and training exercises, stakeholder } \\
\text { inter-agency coordination and } \\
\text { communications }\end{array}$ & $\begin{array}{l}\text { Raw material information: } \\
\text { contact information, scope of } \\
\text { responsibility, capacity } \\
\text { information }\end{array}$ \\
\hline
\end{tabular}


Shaw DR, Achuthan K, Sharma A and Grainger A (2019) Resilience Orchestration and Resilience Facilitation: how government can orchestrate the whole UK ports market with limited resources - the case of UK ports resilience, Government Information Quarterly, (in press).

\begin{tabular}{|l|l|l|}
\hline $\begin{array}{l}\text { Trade associations, e.g. } \\
\text { the British Ports } \\
\text { Association, UK Major } \\
\text { Ports Group }\end{array}$ & $\begin{array}{l}\text { Supporting members, gathering } \\
\text { and sharing information, } \\
\text { identification and advocacy of } \\
\text { members' issues }\end{array}$ & $\begin{array}{l}\text { Information on industry-level } \\
\text { issues and international issues, } \\
\text { sharing best practice, lobbying } \\
\text { (eg better freight rail links) }\end{array}$ \\
\hline
\end{tabular}

Table 2: Port system stakeholders have different roles which generate different concerns and different needs for information and other capabilities.

The huge number of stakeholders produced complexities for the MRPt in three different ways. It was difficult to understand who all the ports system stakeholders were, what capabilities they had and how to motivate them to share these capabilities. First, exactly who all the stakeholders were was not clear to the MRPt or anyone else. Inside each port there were a large number of business that operated different parts of the port and each port was very different. Inside a port the MRPt could ask the port operator for a complete list of firms. But we found that port operators did not know who even nearby stakeholders were outside the port. In our study one port operator mentioned that they did not even know who owned the buildings next door to where the interview was being held, which was just outside the port boundary. So it was difficult for them to say who should or should not be involved in resilience activities. A major problem with trying to describe a whole country's port system was that the number of stakeholders was large and unknown, and changed depending on the reason for asking. For example, a flood defence project for the river Humber included stakeholders from multiple ports, local government and all other stakeholders operating on the same large river (ABP, 2017; Watson, 2017).

Second, the MRPt found it difficult to gather, maintain and use information on what capabilities each of the stakeholders possessed. For example, Deep Port was a GIS database of UK port-related infrastructure for decision-making during crises. However, it proved very difficult to keep that system up to date. Knowledge about capabilities was critical for resilient planning because it was the overall capability of the port to import and export goods that the MRPt tried to make resilient. This overall capability was made up of a capability flow path, the interlinked serial capabilities of stakeholders on the flow path of a cargo which passed through a port (Shaw et al., 2017). Even if a particular stakeholder was known to the MRPt, information on what that stakeholder did or could do to help in a crisis was not easily available. This was important because a key role of resilience planning was to plan alternatives, work-arounds and new options. These included alternative transport routes. For example, 20,000 tonnes of wood pellets are delivered to Drax power station every day from the port of Immingham on the UK's East Coast (Drax, 2018). Even if the rail route between Immingham and Drax was blocked by some crisis there were three other alternative routes and ports available to use (Backhouse, 2017; Drax, 2015).

Another type of alternative capability that we were told about in our interviews was alternative sources of consumables. For example, in the petrol dispute of September 2000 ports depended heavily on the MRPt's capability to influence organisations outside the port (BBC, 2000). The pilots who helped ships to safely sail into UK ports needed petrol for the long drives out to the pilot stations, from which they would then sail out to meet the incoming ships. The MRPt had to persuade the emergency services to let pilots refill their cars with petrol from emergency ambulance depots (Davies, 2015). Some alternative capabilities were owned by the same firms that might have been impacted by a crisis. For example, very large firms like Associated British Ports (ABP) operated several UK ports so if a road blockage 
shut down traffic to one port then ABP could have potentially used the capabilities of another port that it operated. In that situation the firm itself might have recognised the need to use the alternative capability. But when a capability was owned by one firm but needed to be shared with another firm the MRPt might have had to use its influence to ensure this happened. But that required knowledge of this alternative capability's existence in the first place. Efficiency pressures have forced even large firms in the ports industry to have very few redundant or alternative capabilities. These pressures forced significant specialisations on all stakeholders. So knowing the exact specifications of potential alternative and sharable capabilities was critical for the MRPt but very difficult to get.

Third, the MRPt found it difficult to motivate stakeholders to share their capabilities. This was important because the MRPt did not use its own capabilities to provide any of the services that made up the overall function of a port. It relied on ports stakeholders to operate ports and to share the capabilities that other stakeholders might need in a crisis. It also relied on those same stakeholders to share information on the characteristics of the capabilities. Characteristics which included specialisations, capacities and other qualities that would be needed in order to substitute for them if they were removed by a crisis. But port firms did not like to do this because this information was commercially valuable to competitors. So the MRPt found it hard to persuade port firms to share operational capabilities with it, or even to share information on what these capabilities were. Forums, workshops and regulations such as the ISPS code were in operation but there were few incentives for firms within and outside ports to participate in the post-workshop activities which were coordinated by the MRPt.

\subsection{The complexities of using data from new data sources and firms' information systems}

In our study the MRPt's overall attitude was proactive because they sought to get stakeholders to plan ahead for resilience (Shaw et al., 2017). But they did plan extensively and interact with many stakeholders. Although they did wish to be more proactive, for example, to interrogate parts of the ports system to confirm that key capabilities were still functioning using new digital sensors and technologies. For example, a camera could show that a motorway was free from snow. One firm used GPS data from security guards' handheld radios to check the status of their patrols in real-time and RFID chips on containers used location data to prove a journey's progress.

There was a bewildering range of new data sources that the MRPt could potentially harness either directly or via port firms' information systems. This information could help resilience planning by warning of crises or by describing the available alternative capabilities. For example, the UK National Tide Gauge Network provides real-time data on tidal elevations at 44 locations around the UK coast (NTSLF, 2018). These sensors warn of tidal surges which could flood ports. Individual ports maintain their own tide gauges as well (ABP, 2018). Also, the UK's Met Office collects hourly measurements of temperature, wind direction and speed, humidity, visibility, pressure and other observations for approximately 140 locations across the UK (Met Office, 2018). Much additional information was captured by the business information systems used by ports stakeholders themselves not just the sensor networks that they maintained. One example of how the information systems of stakeholder organisations already monitored the health of ports' business capabilities was each port's Automatic Identification System (AIS) system. AIS used radar to find the real-time identifications, positions, courses, and speeds of all nearby ships. 
The business information systems of port operators and the firms that worked in and through ports all could have potentially signalled a loss of capability or an event that would lead to one because controlling different capabilities was their purpose. Even outside ports the traffic flow and average speeds on limited parts of the UK's road motorway network was monitored by the UK's Motorway Incident Detection and Automatic Signalling system (MIDAS) (Summersgill et al., 2005). Different sensors, including MIDAS sensors, were used to estimate journey times and vehicle speeds. And this data was easily accessible on the Web using a Google Maps interface (Highways England, 2018). MIDAS integrates data from sensors such as Automatic Number Plate Recognition (ANPR) cameras, in-vehicle Global Positioning Systems (GPS) and induction loops built into the roads themselves (Highways England, 2016) for 50\% of English roads (Highways England, 2012). In addition to the complexity of many data sources, the types of data available from these sources was also complex. Different sensors gather different information which varied in terms of what the sensors were designed to sense. Cameras, GPS locators and induction loops all collect different data and this changes the granularity and information content of what they provide. Also there were were open data feeds from Network Rail which ran the UK's railway infrastructure (Network Rail, 2018) and there were other open government data sources (Gascó-Hernándeza et al., in press).

All these information capabilities could have helped the MRPt and ports firms to warn of crises and to prepare for them by finding alternative capabilities. But the information overload problems that we saw at the stakeholder organisation level also existed here at the business information systems level, as well. The problems for the MRPt were awareness of which information sources might be useful, judging their quality and then knowing how to integrate and use the highly varied information that they contained.

\subsection{The differences between the MRPt and other ports system stakeholders}

The MRPt had three sets of capabilities that none of the other commercial stakeholders in the ports system had. It had a national focus rather than a focus on one or a few ports; it was concerned with anything that might affect the health of the ports system rather than other aspects of port activities, and it was part of the UK government rather than a type of commercial firm. The MRPt operated on the country level of the UK ports system rather than on the level of any single port or group of ports. This was a challenge when it came to knowing about the details of specific ports and their sub-systems. But it was an advantage when it came to accessing capabilities that were external to a particular port or to all ports. Port level stakeholders including the port authority itself knew little about events outside the port boundary. For example, a ferry operator that we interviewed had to ask a receptionist to monitor traffic reports on television, to watch out for traffic delays on the motorways which led to the port. The ferry operator did this to understand whether trucks would be late for their scheduled ferry crossings of the North Sea.

Ports and their stakeholders also had the greatest difficulty in gaining use of capabilities owned by organisations outside the port. And the MRPt regularly helped them with this. For example, in winter 2007 the UK had a shortage of salt to treat the roads with, to keep them free of ice (BBC, 2010). So Felixstowe port asked the MRPt to persuade the local council to prioritise the port's access roads for "gritting". The MRPt also helped ports with other problems that were outside of their capability to influence. For example, in the Ash Cloud crisis of 2010 half a million UK citizens were stranded abroad when ash from the Eyjafjallajökull volcano prevented them from flying home (House of Lords, 2010). In an 
effort to speed the transportation of people back to the UK the DfT used its derogation capability. It temporarily increased the capability of ferries to carry passengers by easing the legal restrictions on life boat places and on crew to passenger ratios. The MRPt also helped to secure capabilities from organisations that were very far outside the UK ports system. For example the MRPt funded academics to develop MARS, a port simulation tool to help stakeholders to discuss resilience decisions (MARS, 2018).

The MRPt had a different context than commercial ports stakeholders because of its wider geographical scale; its wider criteria of interest in any and all port activities in the UK; its responsibility for maritime as well as land transport; and because it was a part of government. This special context seemed to be a useful capability in itself. Especially if it helped the MRPt to more easily know who all the ports system stakeholders were, to understand how to use stakeholders' capabilities and to motivate stakeholders to share them.

\subsection{Discussion}

Our interviews and our other field data showed how the MRPt's role of sensing and acting on the level of the whole ports system gave it a special context from which to view the UK ports system and with which to deal with the many stakeholders. This helped the MRPt to capture and to some extent integrate a large variety of information from diverse sources. So we call this concept an integration perspective for the whole ports system. The MRPt's integration perspective generated complexity but it also enabled the MRPt to filter-out complexity for itself and for other stakeholders. Next we will explain the concept of integration perspective and how it sometimes enabled the MRPt to orchestrate resilience planning by removing barriers between other stakeholders. We call this removal of barriers to working together resilience facilitation after the concept of trade facilitation which removes "friction" in the trading process (WTO, 2018).

\subsection{The special capability of the MRPt is its integration perspective}

Our data showed that the MRPt had a much larger scale of awareness of the functioning of the ports system than other stakeholders. It had a wide interest in anything to do with the ports system's health. Other stakeholders were too busy and too focused on specific aspects or subsystems. Responsibility for a whole system and the ability of a part of government to actively access information sources made the MRPt open to accepting information about the whole system. The MRPt's integration perspective meant that its staff saw linkages between diverse information that other stakeholders did not see. For example, each port operator might hold information which described their own winter road salt storage levels. But only the staff of the MRPt saw how the readiness of each port related to the readiness of the UK as a whole or how one port might be in a position to help another. This special perspective is consistent with the "Rashomon effect", the concept that individuals may perceive something differently because of their different system perspectives (Roth and Mehta, 2002).

\subsection{An integration perspective is a network orchestrator capability which can filter complexity}

The MRPt's role had strong similarities to the concept of a network orchestrator in the literature. Its integration perspective aggregated and presented the complex possibilities of the system and its environment on an ongoing basis. Its position gave it special access to information as well as a special ability to integrate this information, and use it in ways that other stakeholders could not. It is the very nature of orchestrators and government to be exposed to complexity and the orchestration literature describes different categories of complexity. For example, managing complex alliance networks (Goerzen, 2005); sharing 
tacit knowledge between firms (Dhanaraj \& Parkhe, 2006); employing the competencies of other organisations (Lorenzoni \& Lipparini, 1999; Janssen \& Helbig, 2015); and coordinating between different network levels (Janssen \& van der Voort, 2016, Shaw, 2007).

In our study we saw that this integration perspective, in some cases, was also able to shield MRP staff and other stakeholders from the very complexity that their position afforded them. For example, MRP staff routinely prioritised large scale disruptions over smaller scale ones. They helped stakeholders by defining priorities for the whole UK ports system. The concept of integration perspective is similar to Jakob von Uexküll's idea of an "umwelt" and the MRPt had a different umwelt to other ports stakeholders. An umwelt is a world view which includes access to special sensory data and special capabilities with which to act (Brentari, 2015). Special sensory data and special capabilities create a special context with which to analyse the sensory data and then decide how to act. A world view influences how one thinks and acts not just what one sees. The MRPt and the DfT sometimes used this context to filter complexities. For example, the 2014 Transport Resilience Review itself used a world view that was newly sensitised to extreme weather events on a country-wide scale and over an extended period. And it drew insights about the effects on national transport networks not just network components (Brown, 2014). Following the review's recommendations the DfT has tried to spread awareness of the need for resilience planning to different port stakeholders who might not be aware of the "big picture" and the part they need to play within it.

Our concept of integration perspective is consistent with the ambidextrous principle of adaptive governance because it incorporates the stability and accountability aspects of building and acknowledging "big picture" issues. But it also enables flexible decision-making by using the "big picture" to focus local resources (Wang et al., 2017; Janssen \& van der Voort, 2016). The complexity of a system comes from the potential number of relationships that could potentially link stakeholders not from the number of stakeholders in the system. In our research this meant managing complex configurations of alternative capabilities provided by different stakeholders. The MRPt has the special ability to orchestrate information affordances (Leonardi, 2011). It can make stakeholders selectively aware of different "possibilities for use". Alternatives include borrowing capabilities like spares, consumables or even terminal berths or warehouse space. This produces dynamics, uncertainties and unexpected behaviours, which are confusing because of the number or newness of options that potential relationships present. Generating, testing and choosing between alternative options takes time and cannot be done for all potential crises and all alternative options (Janssen \& van der Voort, 2016). Fortunately the MRPt's integration perspective sometimes allowed it and other stakeholders to avoid complexity by using the "big picture" to prioritise. The MRPt could access stakeholders' goals in the context of the "big picture" to help them to filter out unrequired activities. But the MRPt did not do this routinely because it lacked enough information to always and easily generate the "big picture" and to fully describe stakeholders' goals.

\subsection{Using resilience orchestration and resilience facilitation to support resilience planning}

In our study we saw that the MRPt sometimes orchestrated resilience planning by using the capabilities of its special position in the ports system, its integration perspective and its governmental powers. It did this by facilitating joined-up working between ports stakeholders. The key difference between resilience orchestration and resilience facilitation is that resilience orchestration includes resilience facilitation. Resilience facilitation is concerned with making it easier for ports system stakeholders to work together in resilience 
planning activities by sharing information. In addition to this, resilience orchestration also includes the higher system-level aspects of resilience planning such as planning how to plan. For example, special winter resilience check lists were produced by the MRPt for ports based on learnings from some of the regional port workshops and from previous disruptions. We saw that collecting lower level experiences can enable the MRPt to form higher level learnings that can then be passed back down to support lower level stakeholders (Janssen \& van der Voort, 2016). One role of an orchestrator is to increase the value creation capability of its system of stakeholders (Dhanaraj \& Parkhe, 2006). And a key tool to do this is the ability to influence stakeholders by selectively making them aware of different possibilities that they would value. A network orchestrator creates value by making stakeholders more aware of what is in their individual and mutual best interest, based on their known goals. Here, this included awareness of the efficiency benefits of resilience planning and new or external risks (Shaw et al., 2017).

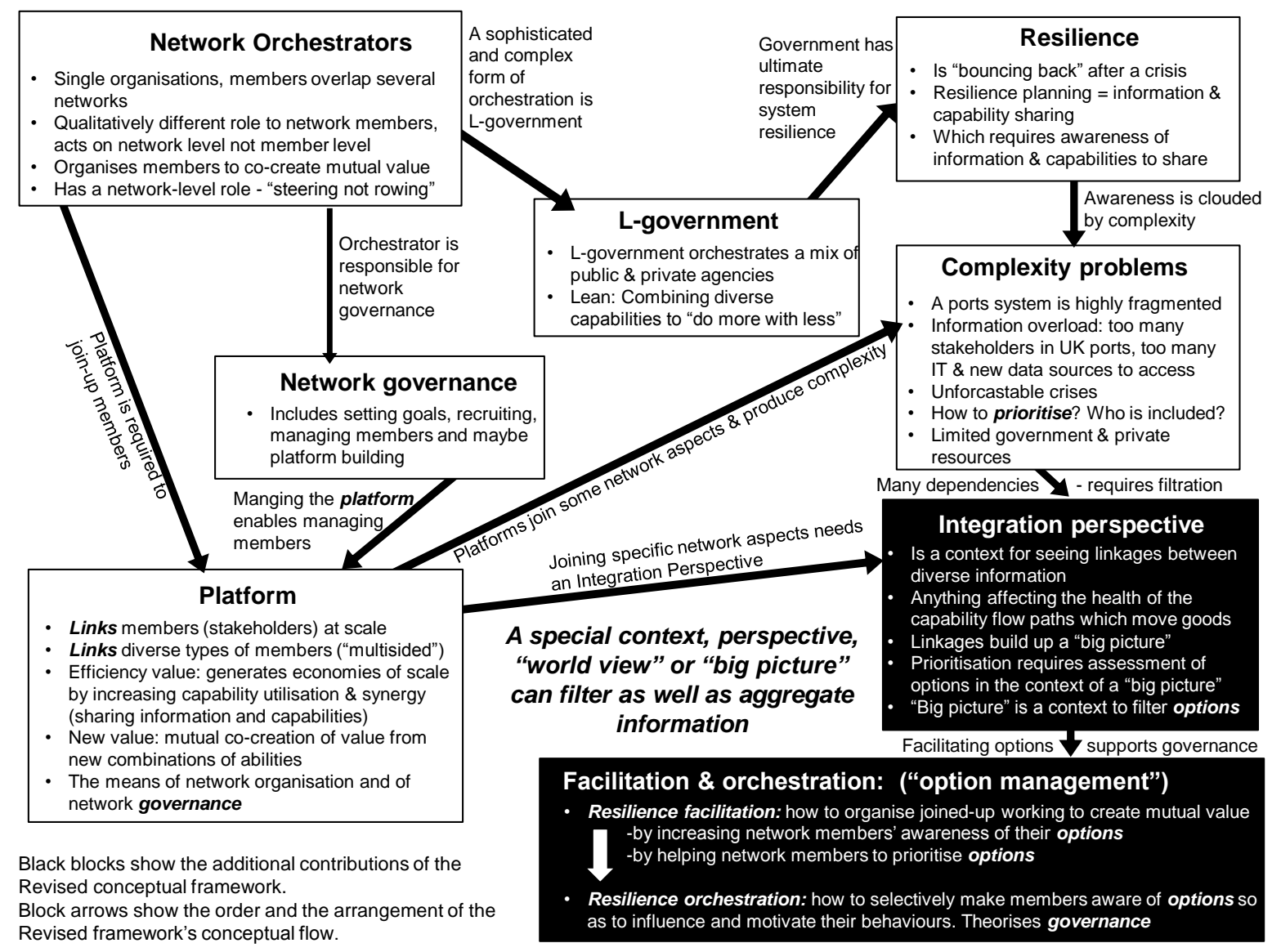

Figure 3: Revised conceptual framework. An orchestrator can build up a "big picture" by aggregation. Then alternative options and other information that are collected can be prioritised against this big picture. So the "big picture" also acts as a contextual filter. The orchestrator facilitates the work of other stakeholders by helping them with greater awareness of options and other information. This includes opportunities for more join-up working and selected options which fit the orchestrator's governance goals.

There are clear advantages to resilience panning activities that come from a better understanding of a stakeholder's options because resilience depends on assembling 
hierarchies of alternative capabilities. But alternatives have to be assembled from many information sources. This has implications for resilience planning in terms of motivating stakeholders to support resilience planning and activities after a crisis. Between them, portsrelated organisations have a huge amount of information from sensors and business IT systems, which can help to prepare for and sense crises. Also, resilience planning requires detailed knowledge of alternative routes, resources and other capabilities to call upon. But persuading organisations to share is difficult and then integrating that information into a "big picture" is even harder. The big picture must be detailed as well as system-wide. It must include information on alternative ports, routes, capacities, capabilities, staff, machinery and consumables. But it would enable the MRPt to make country-level resilience decisions and plans, to optimise its normal operations and to act quickly within a crisis. A big picture of ports stakeholders' capabilities, information needs and operational goals would also help the MRPt to guide stakeholders in their goal choosing; and to motivate then by helping them to work more efficiently together using information sharing. This is consistent with the concept of adaptive governance because it uses lower level system capabilities to enable higher level learnings and advice. Which then flow back to lower level stakeholders as a way of dealing with a complex and uncertain environment (Janssen \& van der Voort, 2016; Wang et al., 2017). An integration perspective can generate a 'big picture', which can be used as an architectural mechanism for self-organised and adaptive coordination.

In summary, Platforms produce complexity by aggregating information and the dependencies that it describes. But they can also provide a special context, perspective, "world view" or "big picture" which can filter information as well. Aggregation helped the MRPt to give ports stakeholders an awareness of more options. The "big picture" helped the MRPt to assess each option within a context. This enabled prioritization. And when the MRPt helped ports firms to prioritise it facilitated their join-up working. Also, selecting which options to make certain stakeholders aware of is a governance tool of network orchestration. Our insight is that platforms enable orchestration by enabling orchestrators to help stakeholders to join-up. At the same time platforms enable orchestrators to govern stakeholders by selecting between possibilities for joining-up. We have summarised this in Figure 3.

\section{Conclusions}

\subsection{Contributions for researchers and managers}

Government and business orchestrators are single organisations which influence and integrate a network of other organisations. Orchestrators are challenged by the complexities of understanding the diverse capabilities and goals of the many different organisations which they orchestrate. Influencing them is also a challenge. The similarities between government and business orchestrators have enabled us to contribute in several ways. First, by focusing on a government department with limited resources we have added to the 1-Government's orchestration literature with the concept of integration perspective. We used this concept to explain how a single orchestrator was able to access the huge range of information sources from stakeholders in a whole market, whilst avoiding information overload. Digital platforms enabled the MRPt to build up a "big picture" of the ports system. A "big picture" which could then be used to filter information and to avoid information overload. Filtration was possible because it enabled aggregated knowledge to be assessed for priority within a wider context. Second, we developed the concepts of resilience orchestration and resilience facilitation. A "big picture" enables an orchestrator to aggregate, filter and prioritise. When the MRPt helped ports firms to prioritise it facilitated their join-up working by helping them to 
collaborate on shared priorities. A significant governance tool for an orchestrator is the ability to choose which options to make stakeholders aware of. Resilience orchestration conceptualises how ports system stakeholders can be motivated to work together more smoothly so that they share their capabilities. This explained why they would cooperate as well as how cooperation was possible. The act of selectively passing on the awareness of certain options is an additional motivator to the 'visible hand' of law-making and the 'invisible hand' of government incentives (Bharosa, 2013). The power of selectively showing options to others enabled us to better conceptualise the facilitation and the governance aspects of orchestration. Third, we have used this research to show how the MRPt could use flow paths of interlinked capabilities to plan resilient alternatives and how ports stakeholders could be motivated to share capabilities and information. Which might have been in return for support in improving their business efficiency or reaching their goals.

\subsection{Limitations and Further Research}

Our aim was to build theory but drawing insights from a single case has external generalisation implications (Lee, 1989). But a single case is appropriate at the start of theory generation (Benbasat et al, 1987) and it does not degrade analytic or theoretical generalisation (Robson, 2002). Our case did not cover international aspects of the global ports system and we chose a single orchestrator. It may be that other organisations orchestrate the same markets using other special capabilities (Janssen \& Estevez, 2013). Other orchestrators may have different "world views". Also, platforms enable orchestration by defragmenting systems. Different platforms link different aspects of their users and defragment different aspects of systems. These would constitute different forms of orchestration with different purposes and benefits for stakeholders. Also, platforms enable orchestration but orchestrators are themselves platforms for network members to use. This suggests a hierarchical 'stack' of platform functionality, which may integrate resources on multiple system levels. Further research is required to investigate the relationships between different orchestration "world views", different "defragmentation platforms" and different levels of resource integration.

\section{Acknowledgements}

We were extremely fortunate to have support from three successive Heads of Resilience Planning at the Department for Transport. They all helped us with information, validation and secure access to DfT related information and personnel; other UK departments; and most importantly introductions to commercial firms and other ports stakeholders. In line with our method the DfT and commercial stakeholders validated our findings at each stage. This work was funded by the EPSRC IDEAS Factory project (blinded); the ESRC Impact Acceleration Programme (blinded); a blinded Travel Bursary; the ESRC IAA Impact Accelerator Fund (blinded); and a DfT/ESRC/ blinded PhD studentship (blinded). We would also like to thanks the three reviews whose suggestions have greatly improved our paper.

\section{References}

ABP (2017). UK'S largest port to improve its resilience to tidal flooding, http://www.abports.co.uk/newsarticle/395/, accessed February 2018.

ABP (2018). Live tide data, Humber Estuary Services, www.humber.com/Live_Information/Live_Tide_Data/, accessed February 2018.

Achuthan, K., Zainudin, N., Roan, J., \& Fujiyama, T. (2015). Resilience of the Food Supply to Port Flooding on East Coast (FO0454). Defra, UK. 
Shaw DR, Achuthan K, Sharma A and Grainger A (2019) Resilience Orchestration and Resilience Facilitation: how government can orchestrate the whole UK ports market with limited resources - the case of UK ports resilience, Government Information Quarterly, (in press).

Akakura, Y., Ono, K., Watanabe, T. \& Kawamura H. (2015). Estimation of alternative ports for container transport after large-scale disasters - Estimation method and application to portBCPs. Journal of Integrated Disaster Risk Management, 5 (2), 135-152.

Aldunce, P., Beilin, R., Handmer, J. \& Howden, M. (2014). Framing disaster resilience The implications of the diverse conceptualisations of "bouncing back. Disaster Prevention and Management, 23 (3), 252-270.

Backhouse, G. (2017). Drax: flexible, affordable, reliable energy. Presentation by Drax Head of Supply Chain \& Logistics at National Infrastructure Expo 2017, https://infrastructure.co.uk/wp-content/uploads/sites/18/2017/02/15.20-Graham-

Backhouse.pptx, accessed February 2018.

BBC (2000). Countdown to crisis: Eight days that shook Britain. http://news.bbc.co.uk/1/hi/uk/924574.stm, accessed February 2018.

BBC (2010). Councils try to keep roads clear despite salt shortage. http://news.bbc.co.uk/1/hi/8449755.stm, accessed February 2018.

Becker, A. \& Caldwell, M.R. (2015). Stakeholder perceptions of seaport resilience strategies: A case study of Gulfport (Mississippi) and Providence (Rhode Island). Coastal Management, 43 (1), 1-34.

Bharosa, N., Klievink, B., Tan, Y.-h. and Janssen, M. (2013). Developing multi-sided platforms for public-private information sharing: design observations from two case studies. 14th Annual International Conference on Digital Government Research June, Canada.

Brentari, C. (2015). Jakob von Uexküll: The Discovery of the Umwelt between Biosemiotics and Theoretical Biology. Springer.

Brown A., Fishenden J., Thompson M., Venters, W. (2017). Appraising the impact and role of platform models and Government as a Platform (GaaP) in UK Government public service reform: Towards a Platform Assessment Framework (PAF). Government Information Quarterly, 34, 167-182.

Brown, R. (2014). Transport Resilience Review: A review of the resilience of the transport network to extreme weather events. DfT, https://www.gov.uk/government/uploads/system/uploads/attachment_data/file/335115/transp ort-resilience-review-web.pdf, accessed February 2018.

Comfort, L.K., Sungu, Y., Johnson, D. \& Dunn, M. (2001). Complex Systems in Crisis: Anticipation and resilience in dynamic environments. Journal of Contingencies and Crisis Management, 9 (3), 144-158.

Davies, M. (2014). Planning for the worst - an agenda for recovery. How ports and their local resilience partners must plan to prepare for and recover from inundation by a North Sea tidal surge. Department for Transport.

Davies, M. (2015). Interview with the DfT's then Head of Resilience Planning and Consequence.

Dhanaraj, C. \& Parkhe, A. (2006) Orchestrating innovation networks. Academy of Management Review, 31 (3), 659-669.

DfT (2015a). Department for Transport organisation chart. Issued as part of a Welcome Pack on 26th April 2016 by DfT office, London. 
Shaw DR, Achuthan K, Sharma A and Grainger A (2019) Resilience Orchestration and Resilience Facilitation: how government can orchestrate the whole UK ports market with limited resources - the case of UK ports resilience, Government Information Quarterly, (in press).

DfT (2015b). Maritime Directorate Information Pack. Department for Transport, November.

DfT (2016). Maritime Security \& Resilience information booklet. Department for Transport.

DfT (2018a). About us, Department for Transport.

www.gov.uk/government/organisations/department-for-transport/about, February 2018.

DfT (2018b). Department for Transport organisation chart,

https://www.gov.uk/government/uploads/system/uploads/attachment_data/file/676611/dft-

organisation-chart.pdf, accessed February 2018.

Drax (2015). Interviews with Drax staff. Drax Power Station, UK, March.

Drax (2018). 5 incredible numbers from the world's largest biomass port, How the UK's largest port keeps the biomass rolling in. Drax, https://www.drax.com/uncategorized/5incredible-numbers-worlds-largest-biomass-port, accessed January 2018.

Gascó-Hernándeza, M., Martin, E.G., Regg, L., Pyo, S. and Luna-Reyes LF (in press). Promoting the use of open government data: Cases of training and engagement. Government Information Quarterly.

GFG (2016). Government Flood group meeting at the Cabinet Office. London, April.

Goerzen, A. (2005). Managing alliance networks: Emerging practices of multinational corporations. The Academy of Management Executive, 9(2), 94-107.

GOV (2018). Local resilience forums: contact details. https://www.gov.uk/guidance/localresilience-forums-contact-details, accessed February 2018.

van Heck, E. \& Vervest, P. (2007). Smart business networks: how the network wins. Communications of the ACM, 50, 6, 28-37.

Hinterhuber, A. (2002). Value Chain Orchestration in Action and the Case of the Global Agrochemical Industry. Long Range Planning, 35, 615-635.

Highways England (2012). Framework Task Specification: Network Services Low Cost Congestion Detection. https://data.gov.uk/data/contracts-finder.../720ee868-9839-4594-a94e395c2b8c10c1, accessed May 2018.

Highways England (2016). Highways England network journey time and traffic flow data. https://data.gov.uk/dataset/highways-england-network-journey-time-and-traffic-flow-data, accessed February 2017

Highways England (2018). WebTRIS traffic flow viewer.

http://webtris.highwaysengland.co.uk/, accessed February 2018.

House of Lords (2010). Eruption of Eyjafjallajökull House of Lords Select Committee Corrected Evidence. 26 July, https://www.parliament.uk/documents/lords-committees/eu-subcom-b/Volcano/cEUB260710ev1.pdf, accesses May 2018.

Hsieh, C.-H., Tai, H.-H. \& Lee, Y.-N. (2014). Port vulnerability assessment from the perspective of critical infrastructure interdependency. Maritime Policy \& Management, 41 (6), 589-606.

Iansiti, M. \& Levien, R. (2004). Strategy as ecology, Harvard Business Review. March, 68-78.

Iyer, B. \& Davenport, T.H. (2008). Reverse Engineering Google's Innovation Machine.

Harvard Business Review, 86 (4), 58-68. 
Shaw DR, Achuthan K, Sharma A and Grainger A (2019) Resilience Orchestration and Resilience Facilitation: how government can orchestrate the whole UK ports market with limited resources - the case of UK ports resilience, Government Information Quarterly, (in press).

Janssen, M. \& Estevez, E. (2013). Lean government and platform-based governance-Doing more with less. Government Information Quarterly, 30, S1-S8.

Janssen, M. \& Helbig, N. (2015). Innovating and changing the policy-cycle: Policy-makers be prepared! Government Information Quarterly, in press.

Janssen, M. \& van der Voort, H. (2016). Editorial: Adaptive governance: Towards a stable, accountable and responsive government. Government Information Quarterly, 33, 1-5.

Klievink, B., Bharosa, N., Tan, Y.-H. (2016) The collaborative realization of public values and business goals: Governance and infrastructure of public-private information platforms. Government Information Quarterly, 33 67-79.

Leonardi, P.M. (2011). When Flexible Routines Meet Flexible Technologies: Affordance, Constraint, and the Imbrication of Human and Material Agencies. MIS Quarterly, 35 (1), 147167.

Lorenzoni, G., \& Lipparini, A. (1999). The Leveraging Of Interfirm Relationships As A Distinctive Organizational Capability: A Longitudinal Study. Strategic Management Journal, 20, 317-338.

Manyena, S.B., O’Brien, G., O'Keefe, P. \& Rose, J. (2011). Disaster resilience: a bounce back or bounce forward ability? Local Environment, 16 (5), 417-424.

MCA (2016). Port Marine Safety Code. Maritime and Coastguard Agency https://assets.publishing.service.gov.uk/government/uploads/system/uploads/attachment_data /file/564723/port-marine-safety-code.pdf, accessed May 2018.

MARS (2018). Methodology for Assessing Resilience of Seaports.

https://www.ucl.ac.uk/resilience-research/people/achuthan/mars, accessed May 2018.

Met Office (2018). UK hourly site-specific observations.

https://www.metoffice.gov.uk/datapoint/product/uk-hourly-site-specific-observations, accessed May 2018.

Miles, M.B. \& Huberman, A.M. (1994). Qualitative data analysis. 2nd edition, Thousand Oaks CA, Sage.

Moller, K. \& Svahn, S. (2006). Role of Knowledge in Value Creation in Business Nets. Journal of Management Studies, 43 (5), 985-1007.

Moller, K., Rajala, A. \& Svahn, S. (2005). Strategic business nets-their type and management. Journal of Business Research, 58, 1274-1284.

Network Rail (2018). Data feed information.

https://datafeeds.networkrail.co.uk/ntrod/login;jsessionid=A276E6AAD32D3A10BB42953D 13E23547, accessed May 2018.

NTSLF (2018). Real-time data - UK National Tide Gauge Network. National Oceanography Centre, http://www.ntslf.org/data/uk-network-real-time, accessed May 2018.

Osborne, D., \& Gaebler, T. (1993) Reinventing government: How the entrepreneurial spirit is transforming the public sector, Penguin Group.

Paul, J.A. \& Maloni, M.J. (2010). Modeling the effects of port disasters. Maritime Economics and Logistics, 12 (2), 127-146. 
Shaw DR, Achuthan K, Sharma A and Grainger A (2019) Resilience Orchestration and Resilience Facilitation: how government can orchestrate the whole UK ports market with limited resources - the case of UK ports resilience, Government Information Quarterly, (in press).

Praditya. D., Janssen, M. and Sulastri, R. (2017). Determinants of business-to-government information sharing arrangements. The Electronic Journal of e-Government, 15 (1), 44-56.

Powell, D. (2015). East Coast Flood Group Review Report. Final version, September 2015. de Reuver, M., Sørensen, C., Basole, R.C. (2017). The digital platform: a research agenda. Journal of Information Technology, 1-12.

Rice, J.B. \& Hoppe, R.M. (2001). Supply chain versus supply chain: the hype and the reality. Supply Chain Management Review, 79 (9/10), September/October, 47-54.

Rowan, S. (2015). MSRD objectives. In Maritime Directorate Information Pack, Department for Transport.

Roth, W.D. \& Mehta, J.D. (2002). The Rashomon Effect combining positivist and interpretivist approaches in the analysis of contested events. Sociological Methods and Research, 31(2), 131-17.

Shaw, D.R. (2007). Manchester United Football Club: developing a Network Orchestration Model. European Journal of Information Systems, 16 (5), 628-642.

Shaw, D.R., Grainger A \& Achuthan K (2017). Multi-level port resilience planning in the UK: How can information sharing be made easier? Technological Forecasting and Social Change, Special issue on Disaster Resilience, 121, 126-138.

Summersgill, I., Fletcher, J.P. \& Mustard, D.C. (2005). MIDA automatic queue protection: full report on safety and congestion relief benefits, unpublished report. http://assets.highways.gov.uk/freedom-of-information/disclosure-log/Technologymaintenance-costs-688024/CRS_688024_Main-Final-Report-21-Dec.pdf, February 2017.

Trepte, K. \& Rice, J.B. (2014). An initial exploration of port capacity bottlenecks in the USA port system and the implications on resilience. International Journal of Shipping and Transport Logistics, 6 (3).

Wang, C., Medaglia, R. \& Zheng, L. (2017) Towards a typology of adaptive governance in the digital government context: The role of decision-making and accountability. Government Information Quarterly, in press.

Watson, D. (2017). Port of Immingham Flood Defence Improvement Project. North East Lincolnshire Council, https://www.nelincs.gov.uk/wp-content/uploads/2017/02/UrgentBusiness-Port-of-Immingham-Flood-Defence.pdf, accessed February 2018.

Welsh, M. (2014). Resilience and responsibility: governing uncertainty in a complex world. The Geographical Journal, 180 (1), 15-26.

WTO (2018). Trade facilitation. https://www.wto.org/english/tratop_e/tradfa_e/tradfa_e.htm, accessed May 2018.

Yin RK (2003) Case Study Research: Design and Methods, Third Edition, Applied Social Research Series, Volume 5, Sage. 